\title{
PELAKSANAAN PUTUSAN ARBITRASE DI INDONESIA
}

\author{
Oleh: HulmanPanjaitan \\ hulman234yahoo.com \\ Universitas Kristen Indonesia, Jakarta, Indonesia
}

\begin{abstract}
Dispute resolution through arbitration has many bene ts, so that the parties prefer to settle their dispute through an arbitration body compared to general justice which requires a long time and relatively large costs. Encouraged by this awareness and future preparations, the Indonesian government has issued Law No. 30 of 1999 concerning Arbitration and Alternative Dispute Resolution. This law has regulated how the proceedings before arbitration and the procedure for implementing the award, both national and international in nature.
\end{abstract}

Keywords: arbitration; Indonesian government; UU No. 30 Tahun 1999; regulation.

\section{Pendahuluan}

Suatu persengketaan dapat diselesaikan melalui jalur pengadilan (litigasi) maupun melalui jalur di luar pengadilan (non litigasi). Penyelesaian sengketa melalui pengadilan lazim dilakukan melalui lembaga Peradilan Umum, yang dirasakan kurang efisien dan efektif karena memerlukan waktu yang relatif lama, disamping ketidak percayaan terhadap lembaga peradilan itu sendiri.

Putusan pengadilan sering dirasakan tidak adil bagi pihak-pihak yang dikalahkan, karena dalam proses penyelesaian perkara di pengadilan suasananya sedemikian konfrontatif, sehingga para pihak dihadapkan pada kenyataan menang dan kalah. Hal ini mengakibatkan selalu adanya upaya dari pihak yang dikalahkan untuk menunda atau mencari peluang memenangkan perkara melalui berbagai upaya hukum, antara lain melalui banding, kasasi dan bahkan peninjauan kembali.

Dilatar belakangi apa yang diuraikan di atas, para pihak yang mengadakan hubungan hukum berupa mencari sarana penyelesaian sengketa yang efisien, cepat dan biaya ringan di luar pengadilan yang dapat dilakukan dengan berbagai cara seperti arbitrase dan alternatif penyelesaian sengketa. ${ }^{1}$

Berbeda dengan asas persidangan lembaga peradilan yang terbuka untuk umum, penyelesaian sengketa melalui arbitrase dilakukan secara tertutup yang dimaksudkan untuk menjaga nama baik para pihak. Penyelesaian sengketa melalui arbitrase, waktunya relatif lebih cepat dibanding dengan penyelesaian sengketa melalui peradilan umum, oleh karena terhadap putusan dewan arbitrase tidak dapat diajukan upaya hukum lain. Putusan dewan arbitrase adalah bersifat final and binding. ${ }^{2}$

Penyelesaian sengketa melalui lembaga arbitrase nasional secara institusional dilalaikan oleh Badan Arbitrase Nasional Indonesia yang bertujuan untuk memberikan penyelesaian yang adil dan cepat, dalam sengketa perdata mengenai soal perdagangan, industri dan keuangan baik yang bersifat nasional maupun yang bersifat internasional.

\footnotetext{
1 Menurut UU No. 30 tahun 1999 tentang Arbitrase dan Alternatif Penyelesaian Sengketa dapat dilakukan melalui konsultasi, negosiasi, mediasi, konsiliasi, atau penilaian ahli.

2 Pasal 60 UU No. 30 tahun 1999 mengemukakan bahwa putusan arbitrase bersifat final dan mempunyai kekuatan hukum tetap dan mengikat para pihak.
} 
Dalam kaitan dengan usaha peningkatan arus penanaman modal asing di Indonesia, pemerintah Indonesia telah pula menanda tangani sejumlah konvensi internasional yang menyangkut penyelesaian sengketa melalui lembaga arbitrase. Diantaranya adalah Konvensi New York tahun 1958 tentang Convention on the Recognition and Enforcement of Foreign Arbitral Awards atau Pengakuan dan Pelaksanaan Putusan-putusan Arbitrase Asing yang disahkan melalui Kepres No. 34 tahun 1981.

Pada tanggal 24 September 1968 Indonesia telah meratifikasi Convention on the Settlement of Investment Disputes between States and National of Other States (ICSID) yaitu Konvensi tentang Penyelesaian Sengketa Investasi antar Negara dan Warga Negara lain yang kemudian diratifikasi melalui UU No. 5 tahun 1968.

Kenyataan dalam praktek peradilan di Indonesia, bahwa suatu putusan dewan arbitrase asing tidak dengan sederhana dapat dilaksanakan. Terdapat putusan pengadilan yang menunjukkan bahwa putusan dewan arbitrase asing tidak dapat dilaksanakan di Indonesia.

Permasalahan yang timbul berkaitan dengan pelaksanaan putusan arbitrase di Indonesia adalah menyangkut kepastian hukum atas putusan arbitrase, yang meliputi upaya hukum yang dapat digunakan para pihak terhadap putusan arbitrase, termasuk sejauhmana putusan arbitrase tersebut baik yang bersifat nasional maupun internasional dapat dilaksanakan di Indonesia. Permasalahan lain adalah adanya ketidak tegasan peraturan perundang-undangan yang mengatur masalah pelaksanaan arbitrase di Indonesia. Sebagaimana diketahui bahwa UU No. 30 tahun 1999 tidak secara tegas mencabut peraturan arbitrase sebelumnya seperti Perma No. 1 tahun 1990 dan apa yang diatur dalam Anggaran Dasar BANI.

\section{Pembahasan}

\section{Penyelesaian Sengketa Melalui Arbitrase di Indonesia}

Arbitrase berasal dari kata "arbitrare" (latin) yang artinya adalah penyelesaian sengketa oleh para wasit. Menurut UU No. 30 tahun 1999, Arbitrase adalah cara penyelesaian suatu sengketa perdata diluar peradilan umum yang didasarkan kepada perjanjian arbitrase yang dibuat secara tertulis oleh para pihak vane bersengketa. Menurut Dr. Tineke Louise Tuegeh Longdong, SH. $\mathrm{MH}^{3}$ arbitrase adalah suatu cara penyelesaian sengketa dengan suatu putusan yang mempunyai kekuatan yang pasti dan tetap berdasarkan hukum atau dengan persetujuan para pihak berdasarkan keadilan dan kepatutan.

Penyelesaian sengketa melalui arbitrase institusional Indonesia dilakukan oleh BANI yang didirikan atas prakarsa KADIN tahun 1977. Penyelesaian sengketa melalui BANI dilakukan dengan pendaftaran permohonan kepada Sekretariat BANI. Selanjutnya arbiter atau Ketua Majelis akan menyampaikan salinan tuntutan kepada Termohon disertai perintah supaya Termohonmemberikanjawaban tertulis selambatlambatnya 14 hari sejak diterimanya salinan tuntutan oleh Termohon. Salinan jawaban Termohon akan diserahkan kepada Pemohon, dan bersamaan dengan itu Ketua Majelis akan menetapkan hari sidang dan memanggil para pihak dalam waktu paling lama 14 hari sejak dikeluarkannya perintah itu.

Dalam jawabannya atau selambat-lambatnya pada sidang pertama, Termohon dapat mengajukan tuntutan balasan dan terhadap tuntutan balasan tersebut, Pemohon diberi kesempatan untuk menanggapi. Tuntutan balasan akan diperiksa dan diputus bersamaan dengan pokok sengketa. Dalam menyelesaikan sengketa, arbiter atau Majelis akan terlebih dahulu mengusahakan perdamaian. Bila upaya perdamaian tidak tercapai, persidangan dilanjutkan dengan memberikan kesempatan terakhir kepada para pihak untuk menyampaikan pendiriannya disertai dengan bukti-bukti yang diperlukan.

Pemeriksaan atas sengketa harus diselesaikan dalam waktu paling lama 180 hari sejak arbiter atau Majelis terbentuk. Semua pemeriksaan perkara dalam sidang arbitrase dilakukan secara tertutup.

\footnotetext{
3 Dr. Tineke Lonis tuegeh Longdong, SH, MH, Asas Ketertiban Umum Dan Konvensi New York 1958, Penerbit Citra Aditya Bakti, Bandung, 1998, hal. 26
} 


\section{Pelaksanaan Putusan Arbitrase di Indonesia}

Dengan dikeluarkannya UU No. 30 tahun 1999 tentang Arbitrase an Alternatif Penyelesaian Sengketa, maka pengaturan tentang pelaksanaan putusan arbitrase nasional yang diselenggarakan secara institusional oleh BANI yang diatur dalam Anggaran Dasar BANI maupun Peraturan Prosedur BANI tidak berlaku lagi sepanjang telah diatur dalam UU No. 30 tahun 1999.

Dalam waktu paling lama 30 hari terhitung sejak tanggal putusan diucapkan, lembar asli atau salinan autentik putusan arbitrase diserahkan dan didaftarkan di Pengadilan Negeri. Putusan Arbitrase adalah bersifat final dan mempunyai kekuatan hukum tetap dan mengikat para pihak. Dalam hal putusan tersebut tidak dilaksanakan secara sukarela, pelaksanaan putusan dilakukan melalui perintah Ketua Pengadilan Negeri atas permohonan salah satu pihak.

Putusan pelaksanaan diberikan waktu paling lama 30 hari sejak permohonan eksekusi. Dalam kaitannya dengan perintah pelaksanaan eksekusi, Ketua Pengadilan Negeri tidak berwenang menilai isi maupun pertimbangan-pertimbangan putusan arbitrase. Ia hanya dibolehkan menolak untuk memberikan perintah pelaksanaan atas pertimbangan bahwa putusan arbitrase telah melanggar ketertiban umum. Perintah pelaksanaan eksekusi akan dituliskan pada lembar asli dan salinan autentik putusan arbitrase.

Khusus mengenai pelaksanaan putusan arbitrase asing di Indonesia didasarkan kepada Konvensi New York tahun 1958 yang dikenal sebagai New York tentang Convention on the Recognition and Enforcement of Foreign Arbitral Awards atau pengakuan dan Pelaksanaan Putusan-putusan Arbitrase Asing yang disahkan melalui Kepres No. 34 tahun 1981.

Dalam pemberlakuan konvensi tersebut di atas, melalui Kepres No. 34 tahun 1981, pemerintah Indonesia mengadakan pembatasan berdasarkan asas resiprositas. Pengakuan pelaksanaan putusan hanya diberikan pada putusan- putusan arbitrase yang dibuat di wilayah negara-negara lain. Pembatasan selanjutnya ialah bahwa konvensi tersebut hanya diperlakukan atas sengketa- sengketa yang timbul dari hubungan- hubungan hukum yang lahir secara kontraktual atau bukan kontraktual yang dianggap sebagai komersial menurut hukum Indonesia.

Selanjutnya ditegaskan bahwa putusan arbitrase yang digunakan dalam konvensi ini tidak hanya meliputi putusan yang dibuat para arbiter yang diangkat untuk setiap kasus saja, tetapi mencakup juga putusan dari badan arbitrase permanen. Dalam pasal 3 diatur mengenai prosedur pelaksanaan, dengan mengemukakan bahwa setiap negara peserta akan mengakui putusan arbitrase sebagai mengikat dan melaksanakannya sesuai dengan aturan-aturan hukum acara yang berlaku dalam wilayah di mana putusan arbitrase tersebut dimohon pelaksanaannya.

Dalam pengajuan permohonan pengakuan dan pelaksanaan putusan arbitrase asing, pihak yang memohon hanya diminta menyerahkan asli atau copy yang secara resmi telah disahkan dan asli perjanjian arbitrase atau copy yang disahkan.

Konvensi membuka kemungkinan untuk menolak pelaksanaan suatu putusan arbitrase asing, dalam halhal berikut :

- Perjanjian arbitrase yang dibuat tidak sah (invalid).

- Satu pihak tidak memperoleh kesempatan untuk melakukan pembelaan, sehingga putusan arbitrase bersangkutan dianggap telah diperoleh secara tidak wajar.

- Putusan arbitrase yang bersangkutan tidak sesuai dengan penugasan yang diberikan.

- Pengangkatan para arbiter atau prosedur arbitrase tidak sesuai dengan perjanjian antara para pihak.

- Putusan arbitrase bersangkutan belum mengikat para pihak, atau telah dikesampingkan di negara dimana putusan tersebut dibuat.

Selanjutnya dalam pasal 5 dijelaskan bahwa putusan arbitrase asing dapat ditolak, apabila pejabat yang kompeten di negara dimana permohonan pelaksanaan putusan tersebut diajukan menganggap bahwa :

Masalah yang dipersengketakan tidak dapat diselesaikan melalui arbitrase menurut hukum negara tersebut.

Pemberian pengakuan dan pelaksanaan putusan 
arbitrase luar negeri bersangkutan akan bertentangan dengan ketertiban umum dari negara tersebut.

Meskipun pemerintah Indonesia telah mengeluarkan UU No. 5 tahun 1968 dan Kepres No. 34 tahun 1981, ternyata bahwa permintaan eksekusi atas putusan arbitrase asing telah mengalami kegagalan. Banyak keluhan dan ketidakpuasan yang dilontarkan oleh pihak asing terhadap sikap peradilan Indonesia yang menonjol untuk mengeksekusi putusan arbitrase asing. Akibatnya Mahkamah Agung akhirnya mengeluarkan Peraturan Mahkamah Agung No. 1 tahun 1990 tentang Tatacara Pelaksanaan Suatu Putusan Arbitrase Asing.

Dengan keluarnya Perma No. 1 tahun 1990 tidak ada keragu-raguan lagi apakah putusan arbitrase asing dapat dilaksanakan di Indonesia. ${ }^{4}$

Perlu dijelaskan bahwa dengan dikeluarkannya UU No. 30 tahun 1999 tentang Arbitrase dan Alternatif Penyelesaian Sengketa, maka tatacara pelaksanaan putusan arbitrase asing yang diatur dalam Perma No. 1 tahun 1990 dinyatakan tidak berlaku sepanjang telah diatur dalam UU No. 30 tahun 1999.

Menurut UU No. 30 tahun 1999 suatu putusan arbitrase asing dapat diakui dan dilaksanakan di Indonesia, apabila :

- Putusan arbitrase asing tersebut dijatuhkan oleh arbiter atau Majelis arbitrase di suatu negara yang dengan negara Indonesia terikat pada perjanjian, baik secara bilateral maupun multilateral, mengenai pengakuan dan pelaksanaan putusan arbitrase internasional.

- Putusan arbitrase internasional tersebut yang menurut hukum Indonesia termasuk dalam lingkup hukum perdagangan yang meliputi perniagaan, perbankan, keuangan, penanaman modal, industri dan hak kekayaan intelektual.

- Putusan arbitrase asing tersebut tidak bertentangan dengan ketertiban umum.

- Putusan arbitrase tersebut telah memperoleh executor dari Pengadilan Negeri Jakarta Pusat.

- Putusan arbitrase yang menyangkut negara RI sebagai salah satu pihak, putusan tersebut dapat diakui dan dilaksanakan apabila telah memperoleh

4 Erman Rajagukguk, Keputusan Arbitrase Asing Mulai Dapat Dilaksanakan di Indonesia, Suara Pembaharuan, 7 Juni 1990. executor dari Mahkamah Agung yang selanjutnya dilimpahkan kepada Pengadilan Negeri Jakarta Pusat.

Melalui UU no. 30 tahun 1999 ditetapkan bahwa yang berwenang menangani pengakuan an pelaksanaan putusan arbitrase asing adalah Pengadilan Negeri Jakarta Pusat. Permohonan pelaksanaan putusan dilakukan setelah putusan diserahkan dan didaftarkan di Pengadilan Negeri Jakarta Pusat, dengan melampirkan :

- Lembar asli atau salinan autentik perjanjian putusan dan naskah terjemahan resminya dalam bahasa Indonesia.

- Lembar asli atau salinan autentik perjanjian yang menjadi dasar putusan dan terjemahan resminya dalam bahasa Indonesia.

- Keterangan dari Perwakilan Diplomatik RI di negara tempat putusan ditetapkan, yang menyatak. in bahwa negara pemohon terikat pada perjanjian baik bilateral maupun multilateral dengan negara RI perihal pengakuan dan pelaksanaan putusan arliitra. se asing.

Setelah Ketua Pengadilan Negeri Jakarta Pusat memberikan perintah eksekusi, maka pelaksanaan selanjutnya dilimpahkan kepada Ketua Pengadilan Negeri yang secara relatif berwenang melaksanakannya.

Dalam kaitan ini, penulis menguraikan jurisprudensi sebagaimana terdapat dalam putusan MA No. 2288/1979 P tanggal 10 Juni 1981 dalam perkara antara PT. Nizwar melawan Navigation Maritime Bulgare. Dalam perkara ini, untuk tingkat pertama melalui Pengadilan Negeri Jakarta Pusat dalam penetapannya No. 2288/1979 P tanggal 10 Juni 1981 telah menetapkan bahwa perusahaan luar negeri Navigation Maritime Bulgare telah memohon agar terhadap termohon PT. Nizwar di Jakarta dapat dilaksanakan keputusan arbitrase yang telah diucapkan oleh arbitrator di London tanggal 12 Juli 1978 untuk membayar jumlah tertentu kepada perusahaan tersebut.

Ketetapan ini membuktikan bahwa masih berlakunya Konvensi Jenewa tahun 1927. Dengan demikian dapat disebutkan bahwa walaupun Kepres 
No. 34 tahun 1981 belum berlaku, sudah ada keputusan Pengadilan Negeri Jakarta Pusat yang membenarkan putusan arbitrase asing dapat dilaksanakan di Indonesia.

Akan tetapi dapat dilihat bahwa Mahkamah Agung berpendapat bahwa putusan arbitrase asing tidak dapat dilaksanakan di Indonesia disebabkan belum adanya peraturan pelaksanaannya walaupun sudah ada Kepres No. 34 tahun 1981. Menurut Mahkamah Agung, bahwa selanjutnya Kepres No. 34 tahun 1981 sesuai dengan praktek hukum yang masih berlaku harus ada peraturan pelaksanaannya tentang apakah permohonan eksekusi putusan hakim arbitrase dapat diajukan langsung pada Pengadilan Negeri, kepada Pengadilan Negeri yang mana, ataukah permohonan eksekusi diajukan melalui Mahkamah Agung.

Perbedaan sikap ini pada dasarnya menyangkut pengertian konvensi yang bersifat self executing yang berbeda dengan konvensi yang bersifat non self executing. Konvensi yang bersifat self executing tidak memerlukan suatu tindakan perundang-undangan untuk dapat berlaku dalam suasana tata hukum nasional, berbeda dengan konvensi yang bersifat non self executing yang memerlukannya.

Bersumber pada kekuatannya sendiri, suatu konvensi internasional yang self executing memberlakukan dirinya sebagai bagian dari tata hukum nasional suatu negara peserta. Perjanjian internasional yang self executing merupakan suatu bentuk dari perundang-undangan internasional.

\section{Kesimpulan dan Saran}

Terdapat keragu-raguan, khususnya bagi pihak asing apabila akan menyelesaikan sengketanya melalui badan peradilan Indonesia. Akibatnya, penyelesaian sengketa melalui jalur di luar pengadilan selalu diusahakan, baik melalui arbitrase maupun melalui berbagai cara alternatif penyelesaian sengketa.

Banyak keuntungan yang diperoleh para pihak dengan menggunakan lembaga ai-bitra.se sebagai sarana penyelesaian sengketa. Disamping waktu yang relatif singkat, juga kerahasiaan dari hubungan baik antara para pihak dapat terjaga dengan baik. Pemeriksaan perkara melalui arbitrase sifatnya adalah confidential. Keputusan yang diambil badan arbitrase adalah bersifat final dan binding.

Untuk menyesuaikan pengaturan hukum yang ada selama ini menyangkut arbitrase disamping menghadapi era liberalisasi perdagangan dan investasi, pemerintah Indonesia telah mengeluarkan UU No. 30 tahun 1999 tentang Arbitrase Dan Alternatif Penyelesaian Sengketa. UU ini telah mengatur proses beracara melalui arbitrase yang bersifat nasional dan tatacara pelaksanaan putusan arbitrase baik yang bersifat nasional maupun yang bersifat internasional.

Namun disatu sisi, kehadiran UU No. 30 tahun 1999 tidak secara tegas menetapkan sikapnya terhadap sejumlah peraturan arbitrase yang ada sebelumnya, khususnya yang terdapat dalam Rv dan Peraturan Mahkamah Agung No. 1 tahun 1990. Oleh karenanya diperlukan aturan pelaksana dari UU no. 30 tahun 1999 tersebut, khususnya penegasan terhadap kedudukan aturan arbitrase sebelumnya.

Demikian juga, mengingat keenganan pihak asing untuk menyelesaikan sengketanya melalui jalur pengadilan, maka kiranya wibawa dan penegakan hukum di Indonesia merupakan tujuan utama dalam pembangunan hukum nasional. Masih diperlukan upaya untuk lebih mensosialisasikan UU No. 30 tahun 1999 untuk dapat berlaku efektif dalam kehidupan perdagangan nasional maupun internasional.

\section{Daftar Pustaka}

A.G. Kartasapoetra, Drs., A. Setiady, Manajemen Penanaman Modal Asing, Penerbit Bina Aksara Jakarta, 1985.

Sudargo Gautama, Prof. Mr. Dr, Perkembangan Arbitrase Dagang Internasional di Indonesia, Penerbit PT. Eresco Bandung, 1989.

Arbitrase Dagang Internasional,

Penerbit Alumni Bandung, 1989.

Indonesia Dan Arbitrase Internasional, Penerbit Alumni Bandung. 1986.

Hukum Dagang Dan Arbitrase Internasional, Penerbit Citra Aditya Bakti. 1991. Hukum Dagang Internasional, Penerbit Alumni Bandung, 1980.

Elkoun, Frank et.al, How Arbitration Works, Washington, 1974. 
Huala Adolf, Hukum Arbitrase Komersial Internasional,

Penerbit Raja Garfindo Persada Jakarta, 1994.

Erman Rajagukguk, SH, Penerapan

Konvensi New York 1958,

Navigation Maritime Bulgare v PT.

Nizwar, Hukum Dan Pembangunan

No. 2 tahun XVI, April 1986.

- Keputusan Arbitrase

Asing Mulai Dapat Dilaksanakan Di

Indonesia. Harian Suara Pembaruan, 7

Juni 1990.

Subekti, Prof. SH. Arbitrase Perdagangan,

Penerbit Bina Cipta Jakarta, 1981.

Memahami Arti Arbitrase, Majalah Varia

Peradilan tahun IV No. 40 Januari

1989. 